\title{
Calcite precipitation forms crystal clusters and muscle mineralization during the decomposition of Cambarellus diminutus (Decapoda: Cambaridae) in freshwater
}

\author{
Bastian Mähler, Kathrin Janssen, Martina Menneken, Mariam Tahoun, \\ Markus Lagos, Gabriele Bierbaum, Christa E. Müller, and Jes Rust
}

\begin{abstract}
The fossilization of soft tissues is generally the replacement of organic structures by pseudomorphs in which muscle tissue is mostly replaced by minerals (i.e., phosphate, carbonate or pyrite). Micro-CT observations of decomposing crayfish in tank and distilled water, show a precipitation of crystal clusters over time. In addition, a mineralized muscle was found by SEM analyses. Raman spectroscopy (CRS) revealed that crystal clusters and the muscle consist of well-ordered calcite. Inductively coupled plasma mass spectrometry (ICPMS) of the distilled water showed a calcium content below the detection limit at the beginning of the experiments, which indicates that most of the calcium ions needed for the precipitation were provided by the decomposing carcasses themselves. Volume measurements of 3D-reconstructed calcite clusters and gastroliths showed a general increase of the volume of calcite clusters and simultaneously volume reduction of gastroliths with progressive decay. Specimens that were in the postmoult phase showed a smaller total volume of precipitated calcite, compared to specimens, which were in the intermoult or premoult phase. In addition, measurements of the total amount of body calcium of Cambarellus diminutus by atomic absorption spectrophotometry (AAS) revealed a higher amount of calcium in individuals without gastroliths than in individuals with gastroliths. It is assumed, that the higher the body size, the higher the volume of precipitated calcite, if the individuals were in the intermoult phase at the time of death. If the individuals were in the postmoult or premoult phase, the phase itself seems to be important.
\end{abstract}

Bastian Mähler. Section: Palaeontology, Institute of Geosciences, Rheinische Friedrich-WilhelmsUniversität Bonn, Nussallee 8, 53115 Bonn, Germany. Corresponding author. bastian.maehler@unibonn.de Kathrin Janssen. Institute of Medical Microbiology, Immunology and Parasitology, Medical Faculty, Rheinische Friedrich-Wilhelms-Universität Bonn, Venusberg-Campus 1, 53127 Bonn, Germany. Kathrin.Janssen@ukbonn.de

\footnotetext{
Mähler, Bastian, Janssen, Kathrin, Menneken, Martina, Tahoun, Mariam, Lagos, Markus, Bierbaum, Gabriele, Müller, Christa E., and Rust, Jes. 2020. Calcite precipitation forms crystal clusters and muscle mineralization during the decomposition of Cambarellus diminutus (Decapoda: Cambaridae) in freshwater. Palaeontologia Electronica, 23(3):a55. https://doi.org/10.26879/992 palaeo-electronica.org/content/2020/2893-decomposing-crayfish 
Martina Menneken. Section Geochemistry, Institute of Geosciences, Rheinische Friedrich-WilhelmsUniversität Bonn, Meckenheimer Allee 169, 53115 Bonn, Germany. mmenneke@uni-bonn.de Mariam Tahoun. Pharmazeutisches Institut, Pharmazeutische \& Medizinische Chemie, Rheinische Friedrich-Wilhelms-Universität Bonn, An der Immenburg 4, 53121 Bonn, Germany. mtahoun@uni-bonn.de Markus Lagos. Section Geochemistry, Institute of Geosciences, Rheinische Friedrich-Wilhelms-Universität Bonn, Meckenheimer Allee 169, 53115 Bonn, Germany.mlagos@uni-bonn.de Gabriele Bierbaum. Institute of Medical Microbiology, Immunology and Parasitology, Medical Faculty, Rheinische Friedrich-Wilhelms-Universität Bonn, Venusberg-Campus 1, 53127 Bonn, Germany. g.bierbaum@uni-bonn.de Christa E. Müller. Pharmazeutisches Institut, Pharmazeutische \& Medizinische Chemie, Rheinische Friedrich-Wilhelms-Universität Bonn, An der Immenburg 4, 53121 Bonn, Germany. orcid.org/0000-00020013-6624 christa.mueller@uni-bonn.de Jes Rust. Section: Palaeontology, Institute of Geosciences, Rheinische Friedrich-Wilhelms-Universität Bonn, Nussallee 8, 53115 Bonn, Germany. jrust@uni-bonn.de

Keywords: crayfish; gastroliths; calcium; fossilization; carbonate; $\mu-\mathrm{CT}$

Submission: 19 April 2019. Acceptance: 11 November 2020.

\section{INTRODUCTION}

During the last 25 years, actuopaleontological studies of taphonomy have been performed by several scientists to shed light upon the conditions that are responsible for soft tissue preservation in the fossil record (Sansom, 2014; Briggs and McMahon, 2016). Soft tissues are not originally preserved, but occur as so called pseudomorphs that are generally formed by the replacement of the tissue by phosphates (e.g., Wilby and Whyte, 1995; Martill, 1988; Briggs et al., 2005; Briggs et al., 2011), carbonates (e.g., Wilby et al., 1996; Briggs et al., 1997; McCobb et al., 1998; Briggs et al., 2011), or pyrite (e.g., Wilby et al., 1996; Briggs, 2003; Schiffbauer et al., 2014; Farrell, 2014). In some cases, soft tissues can be organically preserved (Wiemann et al., 2018). Interactions between biotic and abiotic factors play an important role in these processes. For example, the $\mathrm{pH}$ value (abiotic factor) inside and around a carcass can be influenced by microbial activities (biotic factor) during decomposition (Berner, 1968; Vass, 2001). Fluctuations in the $\mathrm{pH}$ value caused by microbial activities can lead to the precipitation of crystal clusters composed of aragonite or calcite ( $\mathrm{pH}$ increase) or soft tissue replacement by apatite (pH decrease) (Briggs and Kear, 1993; 1994; Briggs and Wilby, 1996; Sagemann et al., 1999; Raff et al., 2008).

Briggs and Kear $(1993 ; 1994)$ reported that during their decomposition experiments with shrimps (Crangon crangon) and prawns (Palaemon elegans), in standard artificial seawater, muscle tissues were replaced by calcium phosphate in which the sole source of phosphate were the carcasses themselves. In addition, during their experiments precipitation of calcium carbonate clusters (aragonite) occurred within carcasses. Sagemann et al. (1999) also observed replacement of muscle tissue by calcium phosphate inside the shrimp Crangon crangon decaying in artificial seawater, but noticed precipitation of calcite crystal bundles as it is known from the fossil record (Briggs and Wilby, 1996). Klompmaker et al. (2019) published the first global data set of exceptionally preserved muscles in malacostracans in the fossil record and postulated that muscles are primarily preserved through phosphatization.

The results of this experimental approach demonstrate the possibility of muscle tissue mineralization only by calcite. The phenomenon of calcified muscles is very rare, but known in the fossil record (Jarzembowski, 1980; Wilby et al., 1996; McCobb et al., 1998; Selden, 2001; and Briggs et al., 2011).

\section{MATERIAL AND METHODS}

Individuals of the extant crayfish Cambarellus diminutus were taken from a settled tank community raised in our lab. The animals were kept in 54 $\mathrm{L}$ tanks of $60 \times 30 \mathrm{~cm}$ in size, at a constant temperature of $26^{\circ} \mathrm{C}$. Tanks were filled with pipe water and fortified with "Biotopol C" water conditioner (JBL, GmbH \& Co. KG, Neuhofen, Germany) to neutralize zinc $(\mathrm{Zn})$ and plumbum $(\mathrm{Pb})$ and to remove chlorine $(\mathrm{Cl})$ and bind copper $(\mathrm{Cu})$. The crayfish were fed with nothing but "Crab Natural" (Sera, GmbH, Heinsberg, Germany), a main food 
TABLE 1. Specimen sizes. C, crayfish; tank, tank water; dist, distilled water; ww, wet weight [g]; bs, body size [cm].

\begin{tabular}{lcccccccc}
\hline Sample & ww & bs & Sample & ww & bs & Sample & ww & bs \\
\hline $\mathrm{C} 1_{\text {tank }}$ & 0.26 & 1.90 & $\mathrm{C} 1_{\text {dist. }}$ & 0.39 & 2.10 & $\mathrm{C} 1_{\mathrm{Ca}}$ & 0.52 & 2.70 \\
$\mathrm{C} 2_{\text {tank }}$ & 0.17 & 1.50 & $\mathrm{C} 2_{\text {dist. }}$ & 0.19 & 1.70 & $\mathrm{C} 2_{\mathrm{Ca}}$ & 0.27 & 2.00 \\
$\mathrm{C} 3_{\text {tank }}$ & 0.19 & 1.70 & $\mathrm{C} 3_{\text {dist. }}$ & 0.21 & 1.70 & $\mathrm{C} 3_{\mathrm{Ca}}$ & 0.26 & 2.10 \\
$\mathrm{C} 4_{\text {tank }}$ & 0.20 & 1.70 & $\mathrm{C} 4_{\text {dist. }}$ & 0.25 & 1.90 & $\mathrm{C} 4_{\mathrm{Ca}}$ & 0.22 & 2.20 \\
$\mathrm{C} 5_{\text {tank }}$ & 0.15 & 1.40 & $\mathrm{C} 5_{\text {dist. }}$ & 0.23 & 1.80 & $\mathrm{C} 5_{\mathrm{Ca}}$ & 0.25 & 2.00 \\
$\mathrm{C} 6_{\text {tank }}$ & 0.48 & 2.30 & $\mathrm{C} 6_{\text {dist. }}$ & 0.52 & 2.50 & $\mathrm{C} 6_{\mathrm{Ca}}$ & 0.47 & 2.40 \\
$\mathrm{C} 7_{\text {tank }}$ & 0.42 & 2.30 & $\mathrm{C} 7_{\text {dist. }}$ & 0.24 & 1.70 & & & \\
$\mathrm{C} 8_{\text {tank }}$ & 0.48 & 2.30 & $\mathrm{C} 8_{\text {dist. }}$ & 0.36 & 2.10 & & & \\
$\mathrm{C} 9_{\text {tank }}$ & 0.43 & 2.20 & $\mathrm{C} 9_{\text {dist. }}$ & 0.34 & 1.90 & & & \\
$\mathrm{C} 1_{\text {tank }}$ & 0.41 & 2.20 & $\mathrm{C} 1_{\text {dist. }}$ & 0.31 & 2.00 & & & \\
\hline
\end{tabular}

for crayfish (ingredients can be found in Appendix 1).

Twenty individuals (specimen $\mathrm{C} 1_{\text {tank }}$ to $\mathrm{C} 10_{\text {tank }}$ and $\mathrm{C} 1_{\text {dist. }}$ to $\mathrm{C} 10_{\text {dist. }}$ ), with partly filled guts, were sacrificed by placing them in an atmosphere of carbon dioxide $\left(\mathrm{CO}_{2}\right)$. Specimens were not dried before weighing on a micro scale. Lengths were measured from the anterior tip of the cephalothorax to the end of the abdomen without the telson (Table 1).

For the experiment, the 20 dead specimens $\left(\mathrm{C} 1_{\text {tank }}\right.$ to $\mathrm{C} 10_{\text {tank }} / \mathrm{C} 1_{\text {dist. }}$ to $\left.\mathrm{C} 10_{\text {dist. }}\right)$ were each placed in one sterile Falcon tube $(50 \mathrm{~mL})$ and fixed in place by synthetic filter floss (JBL GmbH \& Co. KG, Neuhofen, Germany) in the middle of the test tube. Ten tubes were then filled with $50 \mathrm{~mL}$ of tank water (tank) and 10 tubes were filled with $50 \mathrm{~mL}$ of distilled water (dist.). Afterwards, tubes were sealed and stored in an incubator (Memmert GmbH \& Co. KG, Schwabach, Germany) at a constant temperature of $30^{\circ} \mathrm{C}$ for 11 days.

\section{Micro Computed Tomography ( $\mu-\mathrm{CT})$}

During the first four days, samples were initially scanned once per day, followed by scans after seven and 11 days using a phoenix|x-ray $v \mid$ tomex s 240 micro-computed-tomography ( $\mu$-CT) scanner (GE Measurement \& Control, Wuntsdorf, Germany) located at the Institute of Geosciences of the University of Bonn. Each data set has a resolution of $30 \mu \mathrm{m}$; the scans were carried out at 120 $\mathrm{kV}$ and $120 \mu \mathrm{A}$. The CT data were processed using the software VGStudio Max 2.0 (Volume Graphics, Heidelberg, Germany) and Avizo 8.1 (FEl Visualization Sciences Group, Burlington, MA) to reconstruct and visualize the precipitated crystal clusters inside the specimens, and the gastroliths located inside the stomach. In addition, Avizo 8.1 was used for volume measurements of polygonal 3D-surface models.

\section{Inductively Coupled Plasma Mass Spectrometry (ICPMS)}

For water analyses, $4 \mathrm{~mL}$ of each test tube were taken and filled in a $5 \mathrm{~mL}$ tube, which had been previously cleaned twice by deionised water [MilliQ] $\left(18.2 \mathrm{M} \Omega^{*} \mathrm{~cm}\right.$ at $\left.25^{\circ} \mathrm{C}\right)$ and dried for two days. Afterwards, water samples in $5 \mathrm{~mL}$ tubes were acidified by $0.2 \mathrm{~mL}$ of concentrated nitric acid $\left(\mathrm{HNO}_{3}[65 \%]\right)$ and stored at $4{ }^{\circ} \mathrm{C}$. The calcium (Ca) content of the sample solutions were determined with an Element 2/XR Sector Field ICP-MS instrument (Thermo Fisher Scientific ${ }^{\mathrm{TM}}$ ) at medium resolution mode in order to avoid contributions from interfering species on the monitored $\mathrm{Ca}$ masses $\left({ }^{43} \mathrm{Ca}\right.$ and ${ }^{44} \mathrm{Ca}$ ). All solutions (including sample solutions, blank solutions, calibration solutions and reference materials) were measured twice and concentration data were derived from both signals, which were finally also compared for consistency. However, only concentrations based on ${ }^{44} \mathrm{Ca}$ signal intensities were eventually used because of generally higher precision. Prior to analysis all solutions were further diluted and adjusted to $\sim 2$ vol. \% $\mathrm{HNO}_{3}$. To correct for instrumental drift, rhodium (Rh) was added as an internal standard (all solutions were adjusted to a final Rh content of 1 $\mu \mathrm{g} / \mathrm{L})$. In addition to the internal standard, also drift monitors were repeatedly measured throughout the analytical sequence in order to allow, if necessary, for the correction of any additional drift that cannot be compensated by the internal standard. To evaluate the Ca content of the sample solutions, a 5-point linear calibration (covering the concentra- 
TABLE 2. Concentration of calcium in tank water and distilled water. STD, standard; < DL, below detection limit.

\begin{tabular}{lcc}
\hline \multicolumn{1}{c}{ Sample } & Tank water & $\begin{array}{c}\text { Distilled } \\
\text { water }\end{array}$ \\
\hline Concentration $[\mu \mathrm{g} / \mathrm{L}]$ & 56.52 & $<\mathrm{DL}$ \\
& 56.11 & $<\mathrm{DL}$ \\
& 55.88 & $<\mathrm{DL}$ \\
& 55.78 & $<\mathrm{DL}$ \\
Mean concentration $[\mu \mathrm{g} / \mathrm{L}]$ & 56.07 & $<\mathrm{DL}$ \\
STD $[\mu \mathrm{g} / \mathrm{L}]$ & 3.3 & \\
\hline
\end{tabular}

tion range between 1 and $10 \mathrm{mg} / \mathrm{L}$ ) was used with calibration solutions that were diluted from a Merck Certipur ${ }^{\circledR} \mathrm{VI}$ certified multi element solution. The calibration was validated with SPS-SW2 (a certified reference material for element analysis in surface water). For this purpose, two different dilutions of SPS-SW2 that lie within the calibrated concentration range (a 2- fold and 4-fold diluted solution with Ca contents of $2.5 \mathrm{mg} / \mathrm{L}$ and $5.0 \mathrm{mg} / \mathrm{L}$ ) were freshly prepared and analyzed.

ICPMS measurements revealed that at the beginning of the experiments an average of 56.07 $\mu \mathrm{g} / \mathrm{mL}$ calcium was contained in tank water. The amount of calcium in distilled water was below the detection limit (Table 2).

\section{Scanning Electron Microscope (SEM)}

On day 11 the altered crayfish samples were removed from the test tubes. Crystal clusters and the mineralized muscle were dissected and coated by a thin layer of gold. Afterwards, samples were scanned with an 'environmental' scanning electron microscope (SEM) unit (TESCAN VEGA).

\section{Confocal Raman Spectroscopy (CRS)}

Crystal clusters and the mineralized muscle were embedded in epoxy resin (Araldite, Huntsman Advanced Materials (UK) Ltd.), ground with silicon carbide and polished with aluminium oxide for confocal Raman spectroscopy. Samples were analysed by a LabRam HR800 Raman spectrometer (Horiba Scientific) using a $784 \mathrm{~nm}$ laser as excitation source, a grating of 600 grooves $/ \mathrm{mm}$, and a $100 \times$ objective with a numerical aperture of 0.9 . The confocal hole size and the spectrometer entrance slit size was set to 1000 and $100 \mu \mathrm{m}$, respectively. With these settings the spectral resolution was $4.55 \mathrm{~cm}^{-1}$. The total exposure time was 2 minutes with four accumulations of $30 \mathrm{~s}$.

\section{Atomic Absorption Spectrophotometry (AAS)}

To analyse the complete amount of calcium inside Cambarellus diminutus, 6 individuals $\left(\mathrm{C}_{\mathrm{Ca}}{ }^{-}\right.$ $\mathrm{C6}_{\mathrm{Ca}}$ ) were taken from a settled tank community of our own breed and sacrificed by placing them in an atmosphere of $\mathrm{CO}_{2}$. Afterwards crayfish were washed in MilliQ and weighed on a micro scale. Lengths were measured from the anterior tip of the cephalothorax to the end of the abdomen without the telson (Table 1). The individuals were then each dried in one ceramic bowl using an incubator (Memmert GmbH \& Co. KG, Schwabach, Germany) at a constant temperature of $105^{\circ} \mathrm{C}$ for 24 hours and afterwards weighed on a micro scale. Each individual was finely ground by using a porcelain mortar and pestle and weighed again. Thereafter, powdered dry crayfish samples were ashed in a porcelain dish for 1 hour at $450^{\circ} \mathrm{C}$ using a muffle oven. Ashes were subsequently dissolved in $2 \mathrm{~mL}$ of $0.5 \mathrm{~N}$ aqueous hydrochloric acid solution, filtered and diluted to $25 \mathrm{~mL}$ with deionized water. A 1:10 dilution was made for each sample and analysed by using a Shimadzu AA-7000 Atomic Absorption Spectrophotometer (Shimadzu Deutschland $\mathrm{GmbH}$ ). Calcium chloride solutions in a concentration range of $0.005-0.03 \mathrm{~g} / \mathrm{L}$ were prepared for constructing a calibration curve (Appendix 2). Measurements were evaluated using the WizAArd Software (Shimadzu Deutschland $\mathrm{GmbH}$ ).

\section{RESULTS}

\section{General Observations}

On day 2 carapaces changed their colouration from greenish-brown to red. On day 3 muscles began to shrink, becoming soft and crumbling by physical contact. On day 6 all carapaces appeared soft, jellylike and translucent. The crayfish specimens were fully articulated to day 11 (end of experiment), if not touched and kept in water.

\section{Micro Computed Tomography ( $\mu-\mathrm{CT}$ )}

$\mu-C T$ images revealed a precipitation of crystal clusters inside the chelipeds of sample $\mathrm{C}_{\text {tank }}$ after two days already. As the decay proceeded, crystalline structures were observed at the ventral side of the cephalothorax, inside the pereiopods, inside the coxa of the pleopods, along the ventrolateral side of the tergites, in the telson, and the uropods (Figure $1.1-4$ ). Specimens $\mathrm{C}_{\text {tank }}, \mathrm{C} 6_{\text {tank }}$, $\mathrm{C} 9_{\text {tank }}$ and $\mathrm{C} 10_{\text {tank }}$ as well as $\mathrm{C} 1_{\text {dist. }}, \mathrm{C} 3_{\text {dist. }}$. $\mathrm{C} 4_{\text {dist. }}, \mathrm{C} 8_{\text {dist. }}, \mathrm{C} 9_{\text {dist. }}$ and $\mathrm{C} 10_{\text {dist. }}$ contained one pair of gastroliths inside their stomach. Volume 

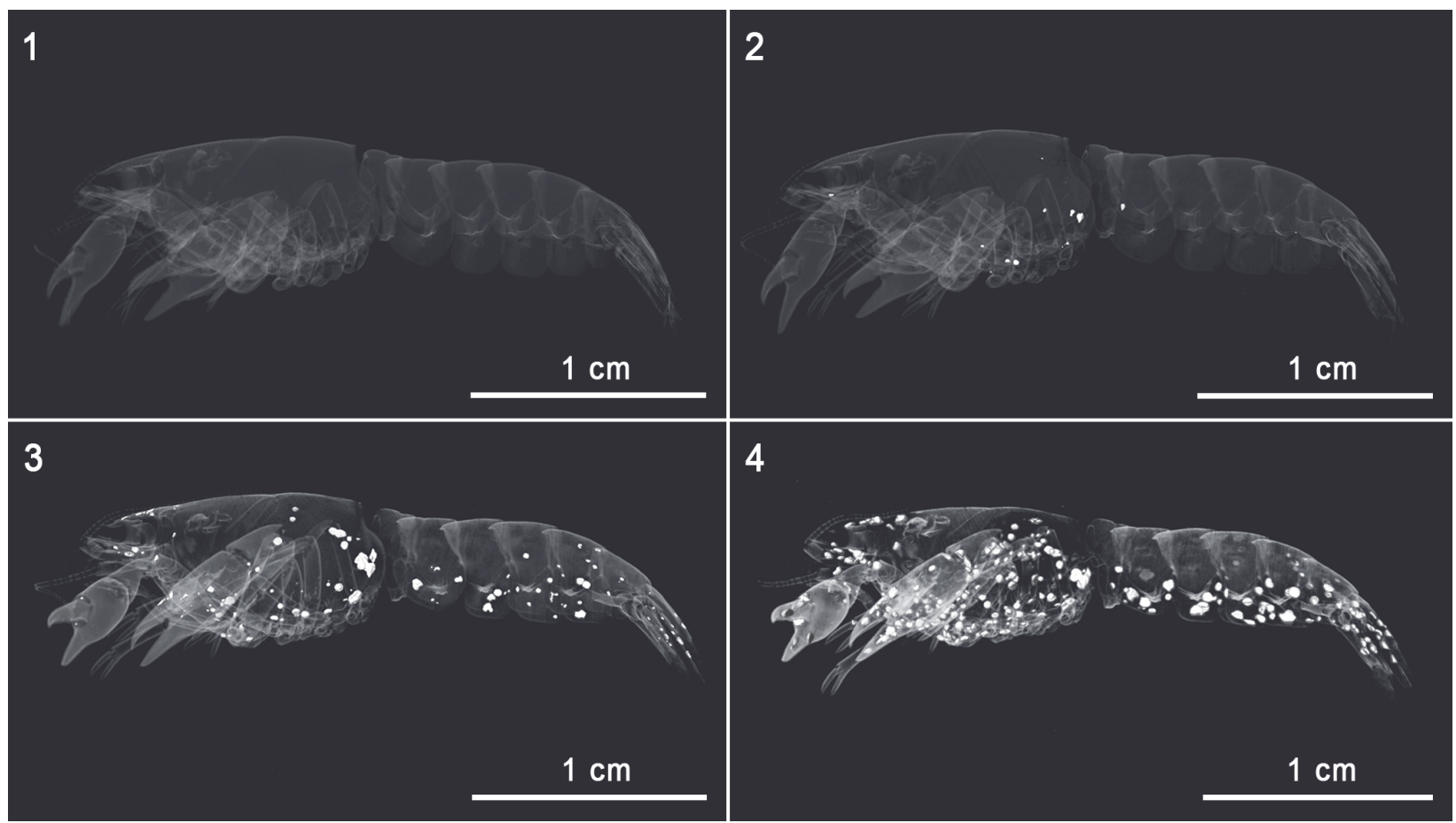

FIGURE 1. Translucent 3D-models of Cambarellus diminutus sample $\mathrm{C} 7_{\text {tank }}$ in combination with 3D-models of calcite clusters, which precipitated inside the carcass during its decomposition in freshwater. 1.1 3D-model without calcite clusters on day 1.1.2 3D-model on day 2 showing a small amount of calcite clusters inside the cephalothorax and the first tergite. 1.3 3D-model on day 4 showing a lot of calcite clusters inside the antennules, the left major propodus, the rostrum, the cephalothorax, the tergites, the uropods, and the telson. 1.4 3D-model on day 7 , showing widespread calcite clusters at the inner side of the carapace of the carcass except the dorsal side of the cephalothorax and the tergites (see also Figure.4.1). 3D-models were reconstructed based on $\mu$-CT data.

measurements of polygonal 3D-surface models of gastroliths in tank and in distilled water showed an increase of the volume of the crystal clusters and a simultaneous volume reduction of gastroliths with progressive decay (Figure 2; see also Appendices 3-10). Further on, most specimens that contained gastroliths showed a smaller total volume of crystal clusters (TVC) compared to specimens without these structures (Figure 3 ). In addition, $\mu-C T$ images revealed that these crystal clusters only precipitated at the inner side of the carapaces (Figure 4.1).

\section{Scanning Electron Microscope (SEM)}

SEM-images show several structures of precipitated crystal clusters (Figure $5.1-5.6$ ) varying in sizes from $260 \mu \mathrm{m}$ to $470 \mu \mathrm{m}$ at the end of the experiment. Most of these structures are spherical (Figure 5.2 and 5.3) or bispherical with mineralized cuticle and plumose setae (Figure 5.1 and 5.6). In addition, some crystal clusters are elliptical and tapering at one side as shown in Figure 5.4. Furthermore, a complete muscle in sample $\mathrm{C} 3_{\text {tank }}$ was mineralized (Figure 6). It was detected inside the dactyl of the chela of the first left pereiopod. The muscle is $700 \mu \mathrm{m}$ in length, slightly bent, thicker at the base and slightly tapering with a slightly rounded top. The muscle fibres are clearly visible. In addition, bacteria, which display rod-shaped structures, were detected on some precipitated clusters (Figure 4.2 - 4.3; Figure 5.6).

\section{Confocal Raman Spectroscopy (CRS)}

Raman analyses clearly revealed that the crystal clusters (Figure 5) and the mineralized muscle of sample $\mathrm{C} 3_{\text {tank }}$ (Figure $6.2-6.3$ ) consist of well-ordered calcite (Figure 7), which can be identified by a sharp band near $1085 \mathrm{~cm}^{-1}$, as well as the presence of lattice vibrations near 154 and $281 \mathrm{~cm}^{-1}$, with the latter being absent in amorphous calcium carbonate (ACC).

\section{Atomic Absorption Spectrophotometry (AAS)}

AAS measurements of calcium content of six individuals of Cambarellus diminutus $\left(\mathrm{C}_{\mathrm{Ca}}-\mathrm{C}_{\mathrm{Ca}}\right.$ [containing gastroliths] and $\mathrm{C}_{\mathrm{Ca}}-\mathrm{C6}_{\mathrm{Ca}}$ [without gastroliths]) revealed that specimens without gas- 


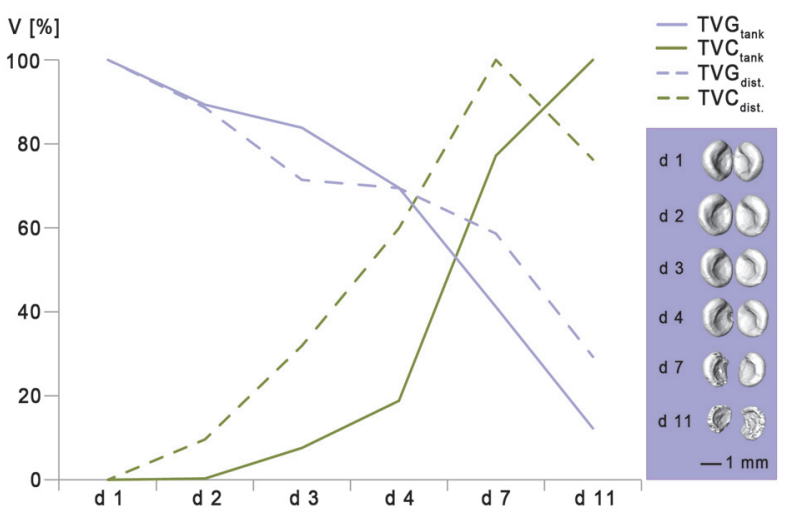

FIGURE 2. Median values of percentage decrease in the total volume of gastroliths ( $T V G_{\text {tank }}$ and $\left.T V G_{\text {dist. }}\right)$ in comparison to the percentage increase in the total volume of calcite clusters $\left(\mathrm{TVC}_{\text {tank }}\right.$ and $\mathrm{TVC}_{\text {dist. }}$ ) of sample $\mathrm{C} 4_{\text {tank }}, \mathrm{C} 6_{\text {tank }}, \mathrm{C} 9_{\text {tank }}, \mathrm{C} 10_{\text {tank }}$ and $\mathrm{C} 1_{\text {dist. }} \mathrm{C} 3_{\text {dist. }}$, $\mathrm{C} 4_{\text {dist. }}, \mathrm{C} 8_{\text {dist. }}, \mathrm{C} 9_{\text {dist. }}$ and $\mathrm{C} 10_{\text {dist. }}$ for the duration of 11 days (Data set can be found in the supplement [Appendix 7-10]). $100 \%$ in TVG tank/dist $_{\text {represents the starting }}$ volume of gastroliths at the beginning of the experiments. $100 \%$ in $\mathrm{TVC}_{\text {tank/dist }}$ represents the maximum volume of calcite precipitation achieved during the experimental period. 3D-models in violet box show the reduction of gastroliths for the duration of 11 days. $\mathrm{V}$, Volume; d, day; TVG, total volume of gastroliths; TVC, total volume of calcite; tank, tank water; dist., distilled water. 3D-models were reconstructed based on $\mu-C T$ data.

troliths contain a higher amount of calcium than individuals with gastroliths (Appendix 7). Specimens $\mathrm{C}_{\mathrm{Ca}}$ and $\mathrm{C}_{\mathrm{Ca}}$ contain both $\sim 1.9 \mu \mathrm{mol} / \mathrm{mg}$ with a gastrolith volume of $7.72 \mathrm{~mm}^{3}$ and 2.12 $\mathrm{mm}^{3}$. Specimen $\mathrm{C}_{\mathrm{Ca}}$ showed a gastrolith volume of $0.2 \mathrm{~mm}^{3}$ and a calcium content of $2.82 \mu \mathrm{mol} / \mathrm{mg}$. Specimens without gastroliths $\left(\mathrm{C}_{\mathrm{Ca}}-\mathrm{C}_{\mathrm{Ca}}\right)$ showed a calcium content of $2.94 \mu \mathrm{mol} / \mathrm{mg}, 3.94$ $\mu \mathrm{mol} / \mathrm{mg}$ and $3.12 \mu \mathrm{mol} / \mathrm{mg}$ (Appendix 11).

\section{DISCUSSION}

In the exoskeleton (i.e., carapace) of crustaceans, calcium carbonate $\left(\mathrm{CaCO}_{3}\right)$ occurs in two forms: As (i) calcite and/or (ii) amorphous calcium carbonate (ACC) (Luquet and Marin, 2004), which both mainly provide the mechanical stability of the carapace (Nagasawa, 2012).

Results of the decomposition experiments employing the freshwater crayfish Cambarellus diminutus, in tank and distilled water, revealed that carapaces softened and continuously thinned out

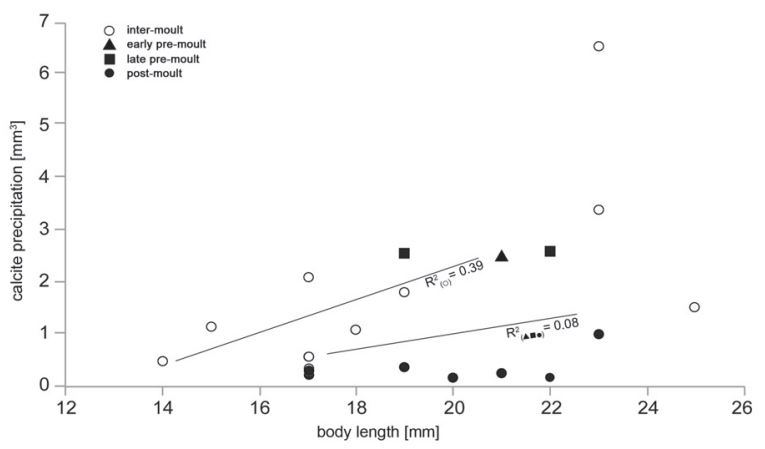

FIGURE 3. Comparison of the maximum volume of precipitated calcite of samples $\mathrm{C} 1_{\text {tank }}$ to $\mathrm{C} 10_{\text {tank }}$ and $\mathrm{C} 1_{\text {dist. }}$ to $\mathrm{C} 10_{\text {dist. }}$ in dependence of the body size. Specimens without gastroliths (which were in the intermoult phase) are marked with a circle. Specimens with gastroliths are marked by using a filled triangle (early premoult phase), filled squares (late premoult phase) and filled circles (postmoult phase). Also shown are regression lines for individuals without gastroliths $\left(R^{2}=0.39\right)$ and with gastroliths $\left(R^{2}=0.08\right)$.

with progressive decay. This likely reflects the acidification of the body fluids inside the carcasses and their immediate surrounding environment, which usually occurs rapidly post mortem (Skopp, 2010; Mähler et al., 2015). The acidification is caused by an enzyme-controlled process called autolysis (Vass, 2001) and by bacterial activity (Skopp, 2010). During the decomposition, bacteria metabolize sugars, which may be derived from chitin (poly$\beta-1,4-N$-acetyl-D-glucosamine) into organic acids and carbon dioxide. These compounds are water soluble and will dissolve in water as carbonic acid (Schoenen, 2013) and lead to a decrease of the $\mathrm{pH}$ value. Under such acidic conditions ACC and calcite inside the cuticle layers dissolve and release calcium ions $\left(\mathrm{Ca}^{2+}\right)$ into the body fluid and the surrounding medium resulting in a softened and thinned carapace.

Simultaneously with the degradation of the exoskeleton, crystal clusters of well-ordered calcite precipitated at the inner side of the carapaces of the carcasses (Figure 4.1), as in the experiments conducted by Briggs and Kear (1994) in which crystal bundles were formed by aragonite. A general increase of these calcite clusters in time can be deduced from polygonal 3D-surface models (Figure 1 and 2). Therefore, the local $\mathrm{pH}$ value at the inner side of the cuticle had to be increased during decay, because $\mathrm{CaCO}_{3}$ will only precipitate by a change of the $\mathrm{pH}$ to more alkaline conditions. It is known that with progressive decay bacteria 

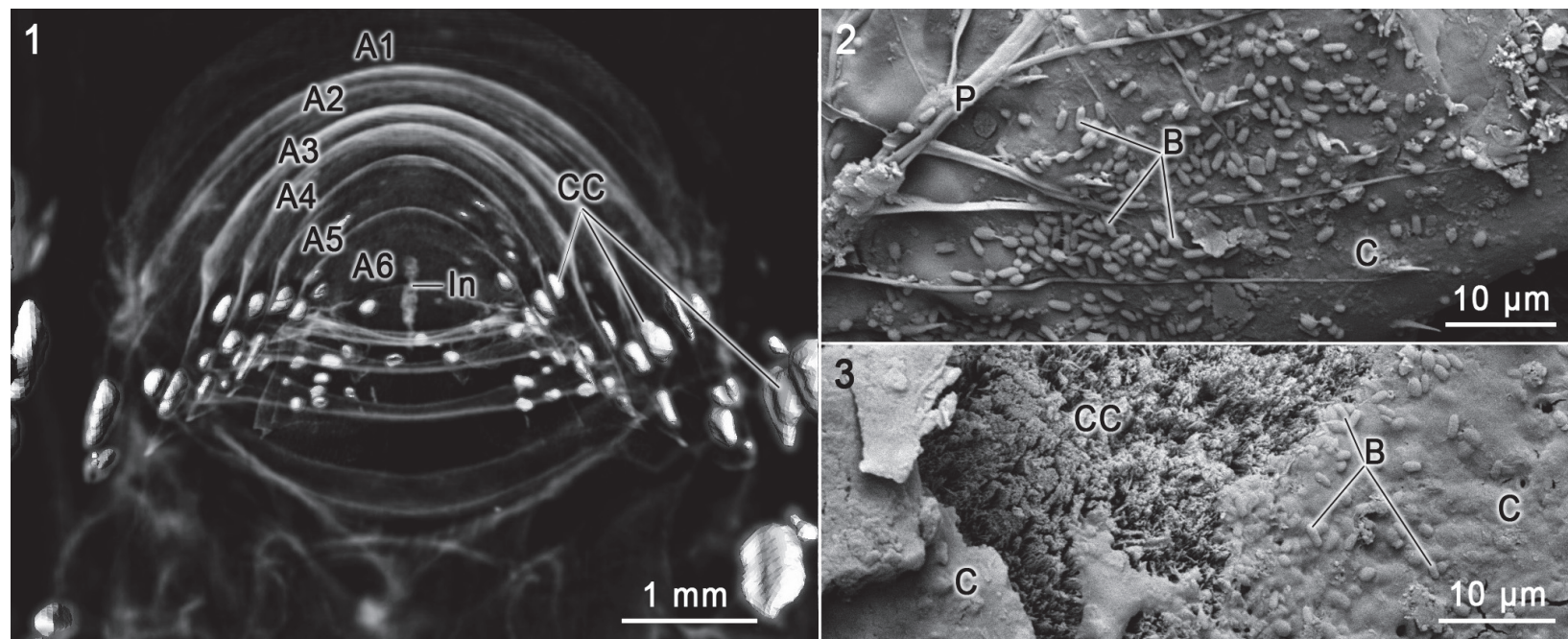

FIGURE 4. 4.1 Anterior view from the cephalothorax into the abdominal region of a translucent 3D model of Cambarellus diminutus sample $\mathrm{C}_{\text {tank }}$ in combination with 3D models of calcite clusters on day 7). 4.2 SEM image of the carapace surface with a plumose seta and some kind of bacteria. 4.3 SEM image of the surface of a calcite cluster with parts of the cuticle layers and bacteria. Abbreviations: A, abdominal segment; B, bacteria; C, cuticle; CC, calcite cluster; In, intestine; P, plumose seta. 3D-models were reconstructed based on $\mu$-CT data.

start to degrade soft tissues and produce microbial enzymes, such as ureases and proteases and the bacterial metabolism switches to decomposition of amino acids and urea, leading to an increase of the $\mathrm{pH}$ value and an alkalization of the carcass (Skopp, 2010; Socks-Fischer et al., 1999). Urea is present in the haemolymph of crayfish as a detoxification product (Sharma, 1969) and is hydrolysed to ammonia and carbamate, which spontaneously decompose into a second molecule of ammonia and carbonic acid. In water, the products react to bicarbonate, ammonium and hydroxide ions, which results in an increase of the $\mathrm{pH}$ value. This alkalization of the surrounding area leads to the formation of $\mathrm{CaCO}_{3}$ if soluble calcium ions are present (Hammes et al., 2003; Mobley and Hausinger, 1989). As the bacterial cell wall is negatively charged, it serves as a nucleation site for the mineralization process (Hammes et al., 2003; StocksFischer et al., 1999). This observation is supported by descriptions of crystallized bacteria in the fossil record (Trewin and Knoll, 1999; Westall, 1999) and, likewise, growth of crystalline bacterial biofilms that occlude urinary catheters is a well-known problem in intensive care (Stickler, 2008).

It is thus conceivable, that because of autolytic processes, acidic conditions prevailed around and inside the carcasses. Under such acidic conditions calcium ions could be dissolved out of the cuticle layers (Figure 8.1 and 8.3). Due to the microbial activity inside the biofilm at the carcasses the $\mathrm{pH}$ increases with progressive decay, resulting in a recrystallization of calcium ions as calcite clusters at the inner side of the carapaces (Figure 8.2 and 8.4). This phenomenon of concentrated calcite clusters at the marginal areas of the carapaces were found in fossils like Mesolimulus and Eryma fuciformes from the Solnhofen limestone (Briggs and Wilby, 1996) and Palaeobenthesicymus libanensis from the Sahel Alma Lagerstätte of Lebanon (Audo and Charbonnier, 2011). As in our experiments, calcite clusters have not been observed in the centre of these fossil bodies (Briggs and Wilby, 1996; Audo and Charbonnier, 2011).

In decapods, gastroliths are $\mathrm{CaCO}_{3}$ storages inside the cardiac stomach wall and consist of a network of protein-chitin fibres within calcium precipitated as ACC (Shechter et al., 2008; Luquet, 2013). Among other functions they are important for the restabilization of the carapace after ecdysis. In the moulting cycle crustaceans pass the four stages premoult, moult (ecdysis), postmoult and intermoult (Drach and Tchernigovtzeff, 1967). Initially to each premoult phase, calcium ions are dissolved out of the cuticle layers of the carapace and transported via the haemolymphatic circulatory system to the stomach (Ahearn et al., 2004). Inside the gastrolith cavity located inside the cardiac stomach wall (two anterior lateral specific discoid areas of the monolayered epithelium) (Shechter et al., 2008), $\mathrm{CaCO}_{3}$ solidifies as amorphous calcium carbonate (ACC) under basic conditions to form gastroliths (Travis, 1960; Travis, 1963; Luquet, 


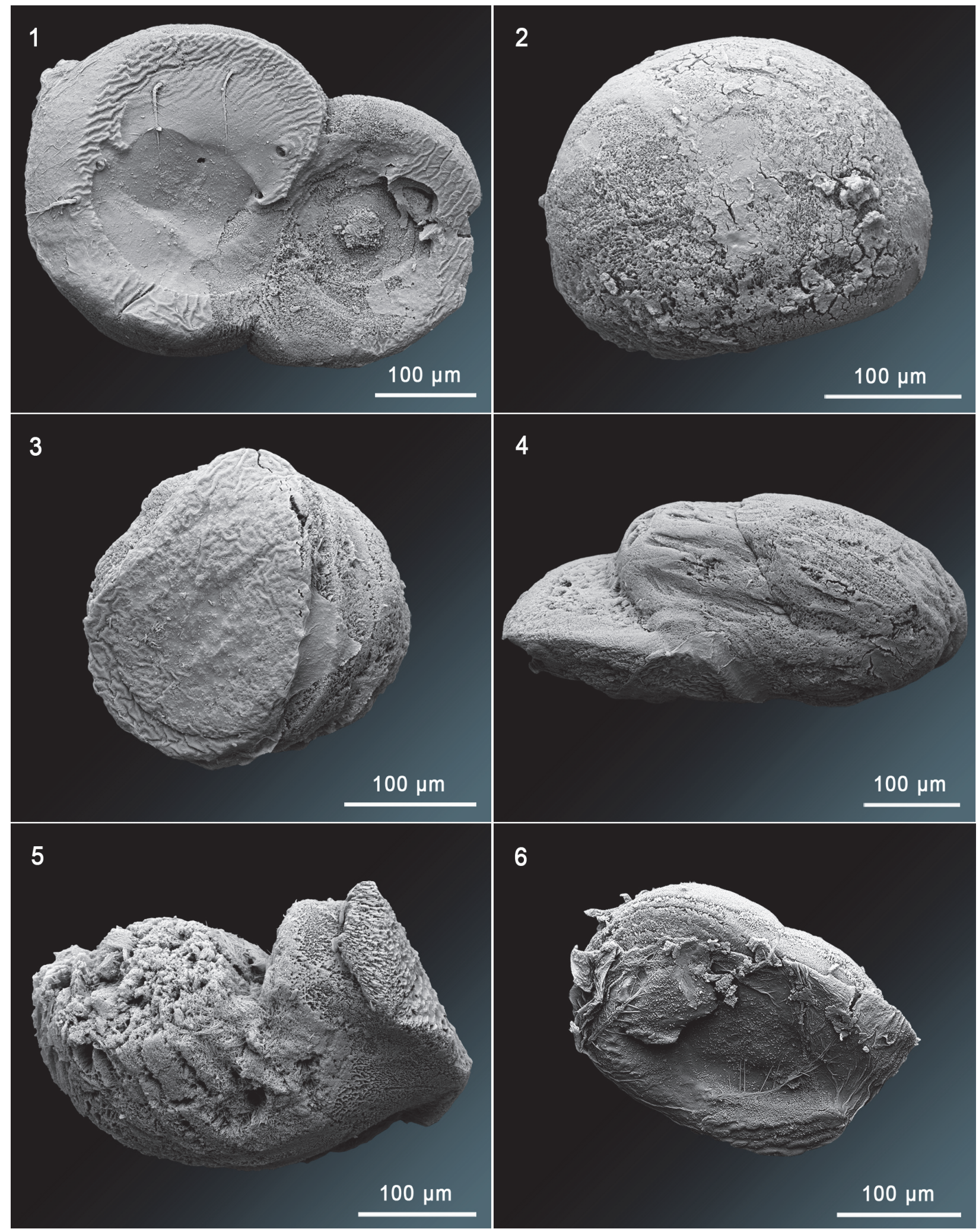

FIGURE 5. SEM-images of several diverse calcite structures which precipitated inside the carcasses. 5.1 Bispherical structure with mineralized setae and a part of the cuticle layers. 5.2 and 5.3 Spherical structures. 5.4 Elliptical structure which is tapering at the left side. 5.5 Complex structure. 5.6 Bispherical structure with mineralized setae and a part of the cuticle layers. 

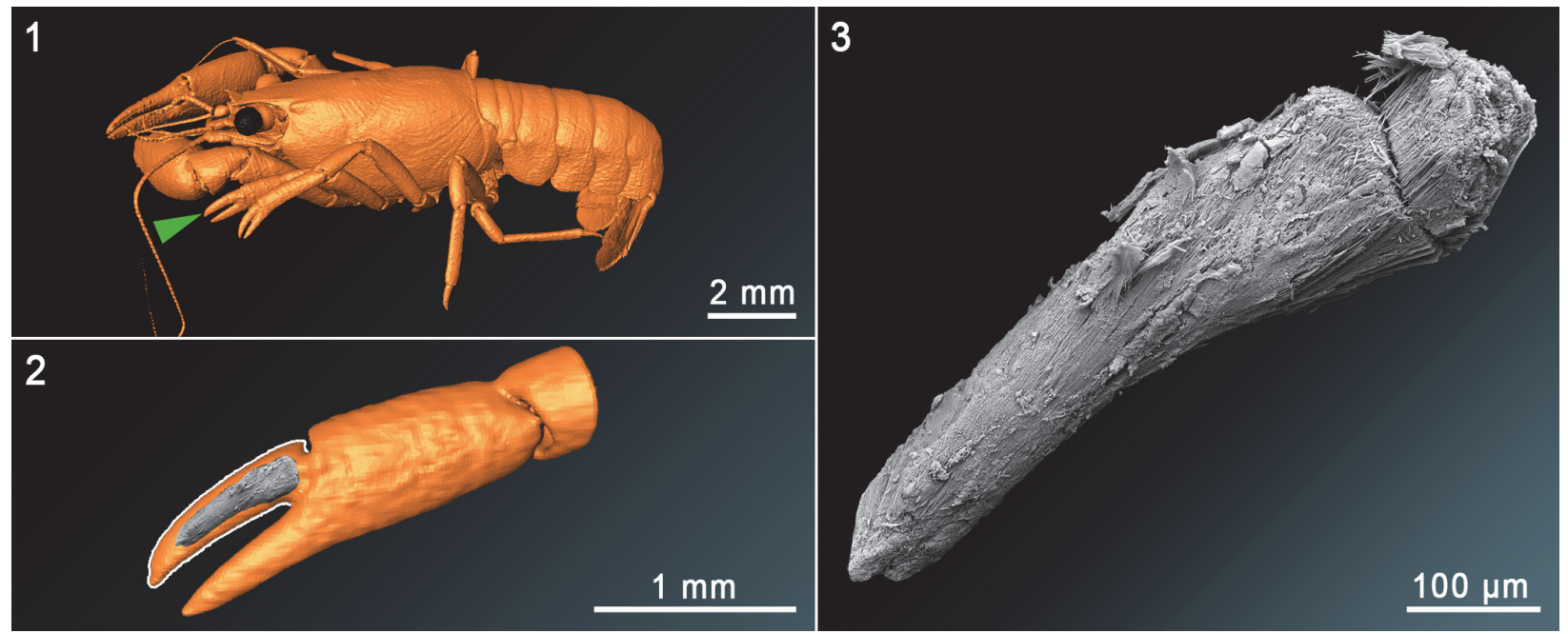

FIGURE 6. 3D-models and SEM-images of sample $\mathrm{C} 3_{\text {tank }} \cdot 6.13 \mathrm{D}$-model of the whole crayfish in dorso-lateral view. 6.2 3D-model of the chela of the first left pereiopod in combination with a SEM-image of the calcified muscle of the dactyl. 6.3 SEM-image of a calcified muscle from the inside of the dactyl of the chela of the first left pereiopod. 3Dmodels were reconstructed based on $\mu$-CT data.

2013), which are separated from digestive secretions by a cuticular lining (Ueno and Mizuhira, 1983). After the moulting gastroliths drop into the gastric lumen where they are digested and calcium ions can be reabsorbed (Ueno and Mizuhira, 1983). However, substantial quantities of calcium

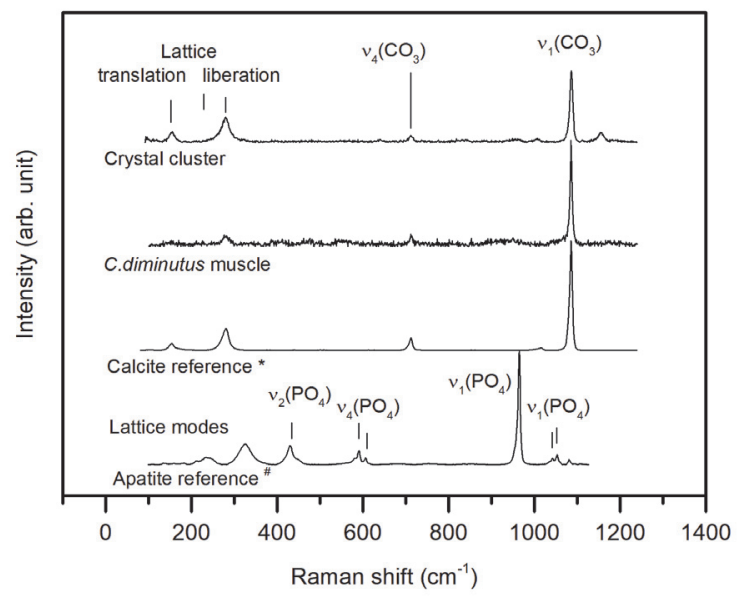

FIGURE 7. Representative Raman spectra of a mineralized muscle of Cambarellus diminutus (sample $\mathrm{C}_{\text {tank }}$ ) and observed crystal clusters compared to Raman reference spectra of crystalline calcite and apatite, taken from the RRUFF Raman data base ( ${ }^{*}$ R040170, \#R060070, Laetsch and Downs, 2006). Raman spectra of the mineralized muscle as well as of the crystal cluster exhibit all main Raman bands typically observed in well crystallized calcite, including the lattice modes, which are absent in amorphous calcium carbonate (Wang et al., 2011). are released to the environment during the moulting phase.

Based on the presence of gastroliths, in individuals used in the decomposition experiments, there were 10 specimens in one of the two moulting phases, premoult or postmoult. In contrast, there were 10 individuals in the intermoult phase because of the absence of gastroliths.

Volume measurements of 3D-reconstructed gastroliths and calcite clusters revealed a volume reduction of gastroliths and simultaneously a general increase of the volume of calcite clusters with on-going decomposition (Figure 2). Consequently, two different $\mathrm{pH}$ values during the decomposition must have occurred inside the carcasses. On the one hand high $\mathrm{pH}$ values on the inner side of the cuticle, because of the precipitation of calcite clusters and on the other hand lower $\mathrm{pH}$ values inside the stomach, because of the continuous volume reduction of the gastroliths. In addition, gastrolith reduction in the experiment is a hint for an intact stomach wall during the decay for a duration of 11 days at $30^{\circ} \mathrm{C}$.

Because of the dissolving of the gastroliths, calcium ions necessary for the precipitation of calcite clusters could be provided (i) by dissolving ACC and calcite out of the cuticle layers, (ii) by free calcium ions inside the haemolymphatic circulatory system and (iii) by dissolving ACC of gastroliths inside the stomach (Figure 8.4). However, volume measurements of polygonal 3D surface models of calcite clusters of crayfish samples, which were in the postmoult phase, showed a smaller total vol- 

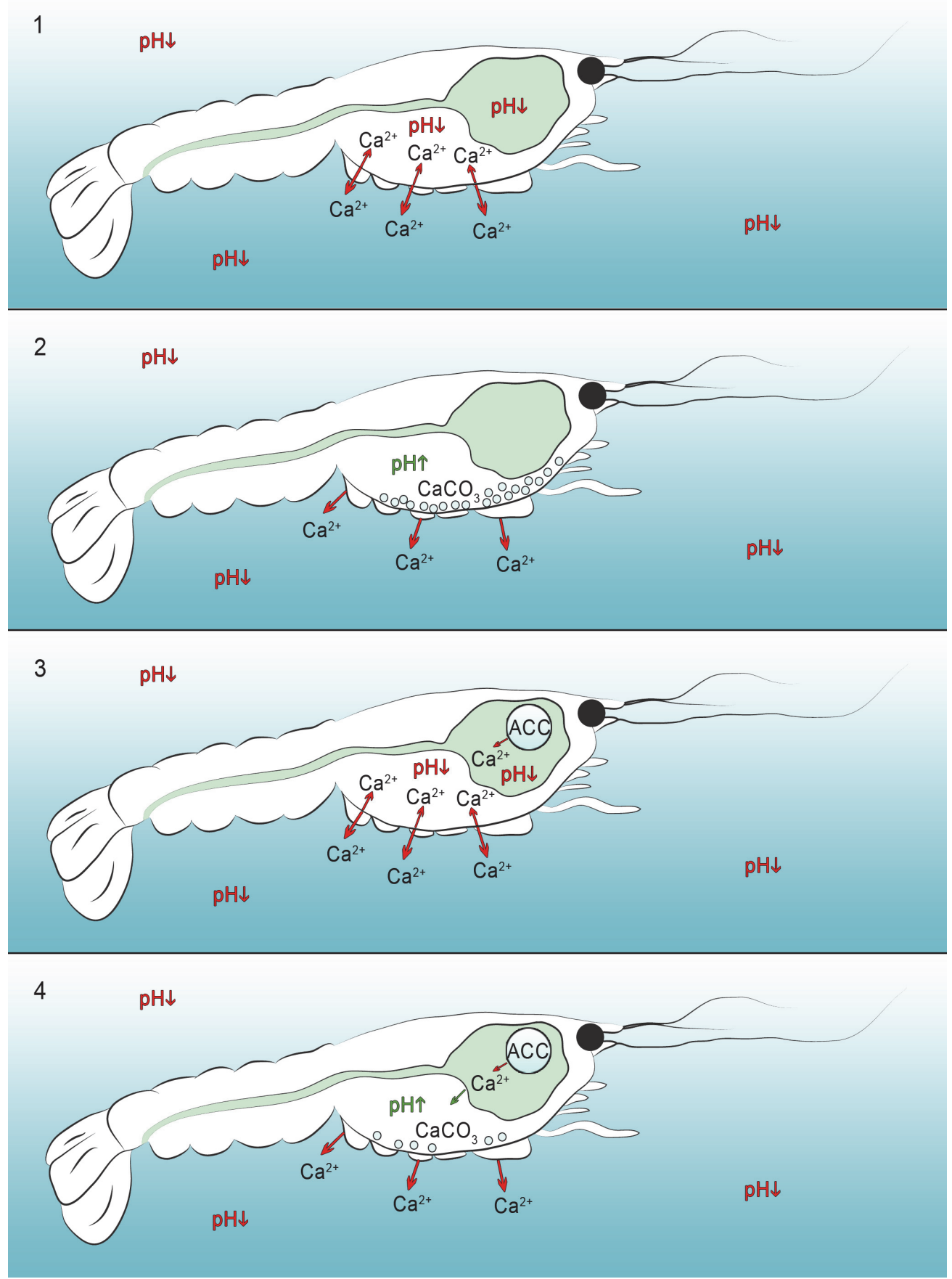

FIGURE 8. Hypothetical scenarios of calcium dissolution and precipitation of calcite clusters inside decomposing crayfish without (8.1-2) and with gastroliths in tank water (8.3-4). 8.1 Low pH-values around and inside the carcass caused by an enzymatic self-digestion (autolysis) and bacterial activity release dissolved calcium ions which migrate out of the carapace into the body cavity and into the environment (red arrows). 8.2 Increase of the pH-value inside the carcass caused by microbial activities during the putrefaction result in a precipitation of calcite clusters at the inner side of the carapace, consisting of previously dissolved calcium ions out of the cuticle layers. $\mathbf{8 . 3}$ Low pH-values around and inside the carcass caused by enzymatic self-digestion (autolysis) and bacterial activity resulted in an accumulation of dissolved calcium ions (red arrows). In addition, low pH conditions inside the stomach and decay of the "gastrolith-cavity-membrane" resulted in dissolving calcium ions from the gastroliths. $8.4 \mathrm{An}$ increase of the $\mathrm{pH}$ value inside the carcass, along the inner side of the carapace, caused by microbial activities during the putrefaction resulted in a precipitation of calcite clusters by previously dissolved calcium ions out of the cuticle layers and gastroliths. 
ume of precipitated calcite (TVC) compared to specimens which were in the intermoult or premoult phase (Figure 3). In addition, calcium measurements of six crayfish individuals $\left(\mathrm{C}_{\mathrm{Ca}}-\mathrm{C}_{\mathrm{Ca}}\right)$ by AAS showed a higher amount of calcium in individuals without gastroliths than in individuals containing big gastroliths like $\mathrm{C}_{\mathrm{Ca}}\left(7.72 \mathrm{~mm}^{3}\right)$ and $\mathrm{C} 3_{\mathrm{Ca}}\left(2.11 \mathrm{~mm}^{3}\right.$ ) (Appendix 11). It is assumed that the individuals $\mathrm{C}_{\mathrm{Ca}}$ and $\mathrm{C}_{\mathrm{Ca}}$ were in the early postmoult phase and lost most of their calcium ions during the moulting process. After moulting not enough calcium ions had been taken up by nutrition till the moment of death. However, individual $\mathrm{C} 2 \mathrm{Ca}$ (containing gastroliths) showed a higher amount of calcium $(2.82 \mu \mathrm{mol} / \mathrm{mg})$ than $\mathrm{C} 1_{\mathrm{Ca}}$ and C ${ }_{\mathrm{Ca}}(1.91 \mu \mathrm{mol} / \mathrm{mg}$ and $1.92 \mu \mathrm{mol} / \mathrm{mg})$. It is assumed that this individual was in the early premoult phase, at the time of death, where calcium ions were still inside the cuticle and the haemolymphatic circulatory system. In addition, only a small amount was inside the stomach where gastroliths are normally formed $\left(\mathrm{TVG}_{\mathrm{Ca}}\right.$ of $\left.\mathrm{C}_{\mathrm{Ca}}=0.195 \mathrm{~mm}^{3}\right)$. The same is assumed for sample $\mathrm{C}_{\text {dist }}$ (decomposing in distilled water) in which the volume of gastroliths was quite small $\left(0.077 \mathrm{~mm}^{3}\right)$, but the volume of precipitated calcite on day 7 was as high as in samples without gastroliths $\left(2.52 \mathrm{~mm}^{3}\right)$ (marked in Figure 3 with a triangle; see also Appendix 4 and 6). Individuals like $\mathrm{C}_{\text {tank }}$ and $\mathrm{C} 9_{\text {dist. }}$ (marked in Figure 3 with squares) showed relatively high volumes of precipitated calcite (2.6 $\mathrm{mm}^{3}$ and $2.58 \mathrm{~mm}^{3}$ ) and high volumes of gastroliths $\left(5.08 \mathrm{~mm}^{3}\right.$ and $\left.3.44 \mathrm{~mm}^{3}\right)$, because both specimens might be in the late premoult phase, shortly before moulting in which one part of calcium was still bound in the old cuticle, and the other part was bound inside the stomach wall. For individuals which were in the intermoult phase at the time of death, it is assumed that the higher the body size, the higher the maximum of the total volume of precipitated calcite (Figure 3 and Appendix 12). But if the individuals were in the premoult or postmoult phase, only the moulting phase seems to be important for the amount of calcite precipitation and not the body size (Figure 3 and Appendix 12). Therefore, the moulting phase and/or the body size at the time of death might have an impact on the calcite precipitation and maybe on the fossilization process.

As shown by this preliminary study, variations in the precipitated calcite might cause by different body sizes (only in the intermoult phase) and might be influenced by the phase of moulting at the time of death. But variations of precipitated calcite in different individuals might also be caused by different intakes of calcium from the food, because the individuals were taken from a settled tank community where they were fed together. Whether the sex of the crayfish plays an important role in the precipitation of calcite is not known but possible. Sourie and Chaisemartin (1961) found a higher concentration of calcium in the haemolymph of crayfish males than in females. On the other hand, Greenway (1974) found no significant differences in his experiments with the same species.

A precipitation of calcite was noticed in individuals which decomposed in distilled water in which no relevant quantities of calcium were measured at the beginning of the experiment (Table 2). Consequently, calcium ions, which are needed for the precipitation of calcite clusters, were mostly provided from the crayfish individuals themselves.

Wilby et al. (1996) published a digenetic sequence in which soft tissues of Dollocaris ingens, discovered from the marine KonservatLagerstätte of La Voulte-sur-Rhône, were first stabilized by apatite, later replaced by calcite and afterwards coated or replaced by pyrite. Jauvion et al. (2019) investigated the fossil of Dollocaris ingens again, along with another specimen of $D$. ingens discovered from the same locality and presented the thesis that an early precipitation of fluorapatite and pyrite was responsible for the exceptional preservation of soft tissues and anatomical details. They suspect further that Mg-calcite precipitated afterwards, while the sediment was still soft, and protected the individuals and formed the concretions (Jauvion et al., 2019). Klompmaker et al. (2019) postulated that muscle tissues in malacostracans are primarly preserved through phosphatization, and because of taphonomic experiments conducted by Briggs and Kear (1993 and 1994) or Sagemann et al. (1999), phosphatization (apatite) seems to be the natural way of muscle tissue preservation. However, nearly most of the experiments conducted before were carried out with marine and/or artificial seawater to simulate marine conditions. In our experiments fresh water was used, and it could be shown that the muscle tissue of sample $\mathrm{C} 3_{\text {tank }}$ (Figure 6) was only replaced by calcite (Figure 7 ). Even if it could only be proven in one individual, we demonstrate that under freshwater conditions muscle tissue can be stabilized by calcium carbonate early in the decomposition process. This phenomenon of muscle preservation by calcite in the fossil record is very 
rare but known from invertebrate fossils discovered from the lacustrine limestones of the insect bed of Bembridge Marls in England (McCobb et al., 1998). Jarzembowski (1980) found in this locality calcified muscle tissue inside the abdomen of a butterfly and McCobb et al. (1998) found calcified muscle fibres and sarcolemma in two of fifteen examined insect fossils. Based on the results of Jarzembowski (1980) and McCobb et al. (1998), Selden (2001) assumed that the muscle fibres of an Eocene spider (Vectaraneus yulei) from Bembridge Marls are also calcified. But muscle tissue preservation by calcite is also known from the Jurassic marine biota of La Voulte-sur-Rhône in France (Wilby et al., 1996) or from Montecaris gogensis discovered from the Upper Devonian Gogo Formation in Western Australia (Briggs et al., 2011).

\section{CONCLUSIONS}

The precipitation of calcite clusters and the mineralization of muscle tissue in crayfish carcasses under freshwater conditions at $30^{\circ} \mathrm{C}$ occur early in the decomposition process. In addition, the difference in the total volume of calcite clusters in different individuals is due to the amount of calcium ions inside the cuticle layers, the haemolymphatic circulatory system and the gastroliths at the time of death, and the chemical conditions of the surrounding medium. It seems that the precipitation of diverse, calcified structures during the decomposition of Cambarellus diminutus in tank (freshwater) and distilled water depends on the body size when individuals are in the intermoult phase at the time of death. But in individuals which were in the pre- moult or postmoult phase, the body size plays a subordinate role. In this case the phases of the moulting cycle might have a higher impact on the precipitation of calcite. In addition, the absence of gastroliths might favour the precipitation of calcite. Whether the absence of gastroliths favours the mineralization of muscle tissue (like in sample $\mathrm{C} 3_{\text {tank }}$ ) has to be proved in further experiments. To validate the results of this experimental approach, an experimental setup with a larger number of individuals and a permanent measurement of the $\mathrm{pH}$ values inside and outside the specimens will be conducted.

\section{ACKNOWLEDGEMENTS}

We thank J.A. Schultz and R. Schellhorn for their splendid support and fruitful discussions, and we thank T. Martin for providing us the $\mu$-CT device (all Section Paleontology, Institute of Geosciences). We thank J. Barthel, O. Dülfer, P. Göddertz, G. Oleschinski and K. Schmeling (all Section Paleontology, Institute of Geosciences) for their support. Further on, we thank M.X. Morales Garcia and L. Hippel (both interns at the Institute of Geosciences) for three-dimensional reconstruction of crystal structures. We also thank A. Lamberz-Brendler (Untere Naturschutzbehörde). The first author especially thanks his wife M. Gupta-Mähler for her support. J. Rust, G. Bierbaum and C.E. Müller are funded by the Deutsche Forschungsgemeinschaft (DFG) as part of the DFG research unit FOR2685 "The Limits of the Fossil Record: Analytical and Experimental Approaches to Fossilization." This is contribution number 28 of DFG research unit FOR2685.

\section{REFERENCES}

Ahearn, G.A., Mandal, P.K., and Mandal, A. 2004. Calcium regulation in crustaceans during the molt cycle: a review and update. Comparitive Biochemistry and Physiology Part A: Molecular \& Integrative Physiology, 137(2):247-257. https://doi.org/10.1016/j.cbpb.2003.10.012

Audo, D. and Charbonnier, S. 2011. The crest-bearing shrimps from the Sahel Alma Lagerstätte (Late Cretaceous, Lebanon). Acta Palaeontologica Polonica 58(2):335-349. https://doi.org/10.4202/app.2011.0056

Berner, R.A. 1968. Calcium carbonate concentrations formed by the decomposition of organic matter. Science, 159(3811):195-197. https://doi.org/10.1126/science.159.3811.195

Briggs, D.E.G. 2003. The role of decay and mineralization in the preservation of soft-bodied fossils. Annual Review of Earth and Planetary Sciences, 31:275-301. https://doi.org/10.1146/annurev.earth.31.100901.144746

Briggs, D.E.G. and Kear, A.J. 1993. Decay and preservation of polychaetes: taphonomic thresholds in soft-bodied organisms. Paleobiology, 19(1):107-135.

https://doi.org/10.1017/S0094837300012343 
Briggs, D.E.G. and Kear, A.J. 1993. Fossilization of soft tissue in the laboratory. Science, 259(5100):1439-1442. https://doi.org/10.1126/science.259.5100.1439

Briggs, D.E.G. and Kear, A.J. 1994. Decay and mineralization of shrimps. Palaios, 9:431-456. https://doi.org/10.2307/3515135

Briggs, D.E.G. and McMahon, S. 2016. The role of experiments in investigating the taphonomy of exceptional preservation. Palaeontology, 59(1):1-11. https://doi.org/10.1111/pala.12219

Briggs, D.E.G., Moore, R.A., Shultz, J.W., and Schweigert, G. 2005. Mineralization of soft-part anatomy and invading microbes in the horseshoe crab Mesolimulus from the Upper Jurassic Lagerstätte of Nusplingen, Germany. Proceedings of the Royal Society B, 272:627-632. https://doi.org./10.1098/rspb.2004.3006

Briggs, D.E.G., Rolfe, W.D.I., Butler, P.D., Liston, J.J., and Ingham, J.K. 2011. Phyllocarid crustaceans from the Upper Devonian Gogo Formation, Western Australia. Journal of Systematic Palaeontology 9(3):399-424. https://doi.org/10.1080/14772019.2010.493050

Briggs, D.E.G. and Wilby, P.R., 1996. The role of the calcium carbonate-calcium phosphate switch in the mineralization of soft- bodied fossils. Journal of the Geological Society, 153:665668. https://doi.org/10.1144/gsjgs.153.5.0665

Briggs, D.E.G., Wilby, P.R., Pérez-Moreno, B.P., Luis Sanz, J., and Fregenal-Martínez, M. 1997. The mineralization of dinosaur soft tissue in the Lower Cretaceous of Las Hoyas, Spain. Journal of the Geological Society, 154:587-588. https://doi.org/10.1144/gsjgs.154.4.0587

Drach, P. and Tchernigovtzeff, C. 1967. Sur la method de determination des stades d'intermue et son application générale aux crustacés. Vie et Milieu Serie A: Biologie Marine, 18(3A):595610.

Farrell, Ù.C. 2014. Pyritization of soft tissues in the fossil record: an overview. The Paleontological Society Papers, 20:35-58. https://doi.org/10.1017/S1089332600002795

Greenaway, P. 1974. Total body calcium and haemolymph calcium concentrations in the crayfish Austropotamobius pallipes (Lereboullet). Journal of Experimental Biology, 61:19-26.

Hammes, F., Boon, N., Villiers, J. de, Verstraete, W., and Siciliano, S.D. 2003. Strain-specific ureolytic microbial calcium carbonate precipitation. Applied and Environmental Microbiology, 69(8):4901-4909. https://doi.org/10.1128/aem.69.8.4901-4909.2003

Jarzembowski, E.A. 1980. Fossil insects from the Bembridge Marls, Palaeogene of the Isle of Wight, southern England. Bulletin of the British Museum of Natural History (Geology), 4:237293.

Jauvion, C., Bernard, S., Gueriau, P., Mocuta, C., Pont, S., Benzerara, K., and Charbonnier, S. 2019. Exceptional preservation requires fast biodegradation: thylacocephalan specimens from La Voulte-sur-Rhône (Callovian, Jurassic, France). Palaeontology, 63(3):395413. https://doi.org/10.1111/pala.12456

Klompmaker, A.A., Hyžný, M., Portell, R.W., Jauvion, C., Charbonnier, S., Fussell, S.S., Klier, A.T., Tejera, R., and Jakobsen, S.L. 2019. Muscles and muscle scars in fossil malacostracan crustaceans. Earth-Science Reviews, 194:306-326. https://doi.org/10.1016/j.earscirev.2019.04.012

Laetsch T. and Downs, R.T. 2006. Software for identification and refinement of cell parameters from powder diffraction data of minerals using the RRUFF project and American mineralogist crystal structure databases. Abstracts from the 19th General Meeting of the International Mineralogical Association, Kobe, Japan, 23-28 July 2006.

Luquet, G. and Marin, F. 2004. Biomineralization in crustaceans: storage strategies. Comptes Rendus Palevol, 3(6-7):515-534. https://doi.org/10.1016/j.crpv.2004.07.015

Luquet, G., Fernández, M.S., Badou, A., Guichard, N., Le Roy, N., Corneillat, M., Alcaraz, G., and Arias, J.L. 2013. Comparative ultrastructure and carbohydrate composition of gastroliths from Astacidae, Cambaridae and Parastacidae freshwater crayfish (Crustacea, Decapoda). Biomolecules, 3:18-38. https://doi.org/10.3390/biom3010018

Martill, D.M. 1988. Preservation of fish in the Cretaceous Santana Formation of Brazil. Paleontology, 31(1):1-18.

Mähler, B., Schwermann, A.H., Wuttke, M., Schultz, J.A., and Martin, T. 2015. Four-dimensional virtopsy and the taphonomy of a mole from the Oligocene of Lake Enspel (Germany). Palaeobiodiversity and Palaeoenvironment, 95(1):115-131. https://doi.org/10.1007/s12549-014-0180-x 
McCobb, L.M.E., Duncan, I.J., Jarzembowski, E.A., Stankiewicz, B.A., Wills, M.A., and Briggs, D.E.G. 1998. Taphonomy of the insects from the Insect Bed (Bembridge Marls), late Eocene, Isle of Wight, England. Geological Magazine, 135(4):553-563. https://doi.org/10.1017/s0016756898001204

McWhinnie, M.A. 1962. Gastrolith growth and calcium shifts in the freshwater crayfish, Orconectes virilis. Comparative Biochemistry and Physiology, 7:1-14. https://doi.org/10.1016/0010-406x(62)90021-x

Mobley, H.L.T. and Hausinger, R.P. 1989. Microbial ureases: significance, regulation, and molecular characterization. Microbiological Reviews, 53(1):85-108.

Nagasawa, H. 2012. The crustacean cuticle: structure, composition and mineralization. Frontiers in Bioscience, E4:711-720. https://doi.org/10.2741/e412

Pinheiro, F.L., Horn, B.L.D., Schultz, C.L., Andrade, J.A.F.G. de, and Sucerquia, P.A. 2012. Fossilized bacteria in a Cretaceous pterosaur headcrest. Lethaia, 45:495-499. https://doi.org/10.1111/j.1502-3931.2012.00309.x

Raff, E.C., Schollaert, K.L., Nelson, D.E., Donoghue, P.C.J., Thomas, C.-W., Turner, F.R., Stein, B.D., Dong, X., Bengtson, S., Huldtgren, T., Stampanoni, M., Chongyu, Y., and Raff, R.A. 2008. Embryo fossilization is a biological process mediated by microbial biofilms. Proceedings of the National Academy of Sciences, 105(49):19360-19365. https://doi.org/ 10.1073/pnas.0810106105

Sagemann, J., Bale, S.J., Briggs, D.E.G., and Parkes, R.J. 1999. Controls of the formation of authigenic minerals in association with decaying organic matter: an experimental approach. Geochimica et Cosmochimica Acta, 63(7/8):1083-1095. https://doi.org/10.1016/S0016-7037(99)00087-3

Sansom, R.S. 2014. Experimental decay of soft tissues. The Paleontological Society Papers, 20:259-274. https://doi.org/10.1017/S1089332600002886

Schiffbauer, J.D., Xiao, S., Cai, Y., Wallace, A.F., Hua, H., Hunter, J., Xu, H., Peng, Y., and Kaufman, A.J. 2014. A unifying model for Neoproterozoic-Palaeozoic exceptional fossil preservation through pyritization and carbonaceous compression. Nature Communications, 5:5754. https://doi.org/10.1038/ncomms6754

Schoenen, D. 2013. Verwesung, der mikrobielle Abbauprozess menschlicher Leichen und seine Bedeutung für den öffentlichen Gesundheitsdienst, Hygiene, Friedhofswesen, Bodenkunde, Rechtsmedizin und Kriminologie. Shaker Verlag, Aachen.

Selden, P.A. 2001. Eocene spiders from the Isle of Wight with preserved respiratory structures. Palaeontology, 44(4):695-729. https://doi.org/10.1111/1475-4983.00199

Sharma, M.L. 1969. Trigger mechanism of increased urea production by the crayfish, Orconectes rusticus under osmotic stress. Comparative Biochemistry and Physiology, 30(2):309-321. https://doi.org/10.1016/0010-406X(69)90813-5

Shechter, A., Berman, A., Singer, A., Freiman, A., Grinstein, M., Erez, J., Aflalo, E.D., and Sagi, A. 2008. Reciprocal changes in calcification of the gastrolith and cuticle during the molt cycle of the red claw crayfish Cherax quadricarinatus. The Biological Bulletin, 214:122-134. https://doi.org/10.2307/25066669

Skopp, G. 2010. Postmortem toxicology. Forensic Science Medicine and Pathology, 6:314-325. https://doi.org/10.1007/s12024-010-9150-4

Sourie, R. and Chaisemartin, C. 1961. Les variations de la teneur en calcium de l'hémolymphe chez Astacus pallipes Lereboullet. Vie Milieu, 12:605-613.

Stickler DJ. 2008. Bacterial biofilms in patients with indwelling urinary catheters. Nature Clinical Practice Urology, 5:598-608. https://doi.org/10.1038/ncpuro1231

Stocks-Fischer, S., Galinat, J.K., and Bang, S.S. 1999. Microbiological precipitation of $\mathrm{CaCO}_{3}$. Soil Biology and Biochemistry, 31:1563-1571. https://doi.org/10.1016/s0038-0717(99)00082-6

Travis, D.F. 1960. The deposition of skeletal structures in the Crustacea. I. The histology of the gastrolith skeletal tissue complex and the gastrolith in the crayfish, Orconectes (Cambarus) virilis Hagen - Decapoda. The Biological Bulletin, 118(1):137-149. https://doi.org/10.2307/1539064

Travis, D.F. 1963. Structural features of mineralization from tissue to macromolecular levels of organization in the decapod Crustacea. Annals of the New York Academy of Science, 109(1):177-245. https://doi.org/10.1111/j.1749-6632.1963.tb13467.x

Trewin, N.H. and Knoll, A.H. 1999. Preservation of Devonian chemotrophic filamentous bacteria in calcite veins. Palaios, 14:288-294. https://doi.org/10.2307/3515441 
Ueno, M. and Mizuhira, V. 1983. Calcium transport mechanism in crayfish gastrolith epithelium correlated with the molting cycle. II. Cytochemical demonstration of $\mathrm{Ca}^{2+}-\mathrm{ATP}$ ase and $\mathrm{Mg}^{2+}$ -ATPase. Histochemistry, 80:231-217. https://doi.org/10.1007/bf00495768

Vass, A.A. 2001. Beyond the grave-understanding human decomposition. Microbiology Today, 28:190-192

Wang, D., Hamm, L.M., Bodnar, R.J., and Dove, P.M. 2011. Raman spectroscopic characterization of the magnesium content in amorphous calcium carbonates. Journal of Raman Spectroscopy, 43(4):543-548. https://doi.org/10.1002/jrs.3057

Westall, F. 1999. The nature of fossil bacteria: a guide to the search for extraterrestrial life. Journal of Geophysical Research, 104(E7):16437-16451. https://doi.org/10.1029/1998JE900051

Wiemann, J., Fabbri, M., Yang, T.-R., Stein, K., Sander, P.M., Norell, M.A., and Briggs, D.E.G. 2018. Fossilization transforms vertebrate hard tissue proteins into N-heterocyclic polymers. Nature Communications, 9:4741. https://doi.org/10.1038/s41467-018-07013-3

Wilby, P.R., Briggs, D.E.G., and Riou, B. 1996. Mineralization of soft-bodied invertebrates in a Jurassic metalliferous deposit. Geology, 24(9):847-850. https://doi.org/10.1130/0091-7613(1996)024<0847:mosbii>2.3.co;2

Wilby, P.R. and Whyte, M.A. 1995. Phosphatized soft tissue in bivalves from the Portland Roach of Dorset (Upper Jurassic). Geological Magazine, 132(1):117-120.

https://doi.org/10.1017/S001675680001147X 


\section{APPENDICES}

All appendices are available as PDF files for download at https://palaeo-electronica.org/content/2020/2893-decomposing-crayfish

\section{APPENDIX 1.}

Contents of the feed.

\section{APPENDIX 2.}

Data set and calibration curve for calcium chloride.

\section{APPENDIX 3.}

Total volume of calcite precipitation in crayfish in tank water on day 1 to 4 and day 7 and 11 .

\section{APPENDIX 4.}

Total volume of calcite precipitation in crayfish in distilled water on day 1 to 4 and day 7 and 11 .

\section{APPENDIX 5.}

Total volume of gastroliths of crayfish in tank water $\mathrm{C} 4_{\text {tank }}, \mathrm{C} 6_{\text {tank }}, \mathrm{C} 9_{\text {tank }}$ and $\mathrm{C} 10_{\text {tank }}$ on day 1 to 4 and day 7 and 11 .

\section{APPENDIX 6.}

Total volume of gastroliths of crayfish in distilled water $\mathrm{C} 1_{\text {dist. }}, \mathrm{C} 3_{\text {dist. }}, \mathrm{C} 4_{\text {dist. }}, \mathrm{C} 8_{\text {dist. }}, \mathrm{C} 9_{\text {dist. }}$ and C10 dist. on day 1 to 4 and day 7 and 11.

\section{APPENDIX 7.}

Total volume of gastroliths in percent (\%) for day 1 to 4 and day 7 and 11 of crayfish sample $\mathrm{C} 4_{\text {tank }}, \mathrm{C} t_{\text {ank }}, \mathrm{C}_{\text {tank }}$ and $\mathrm{C} 10_{\text {tank }}$ in tank water.

\section{APPENDIX 8.}

Total volume of gastroliths in percent (\%) for day 1 to 4 and day 7 and 11 of crayfish sample $\mathrm{C} 1_{\text {dist. }}, \mathrm{C} 3_{\text {dist. }}, \mathrm{C} 4_{\text {dist. }}, \mathrm{C} 8_{\text {dist. }}, \mathrm{C} 9_{\text {dist. }}$, and $\mathrm{C} 10_{\text {dist. }}$ in distilled water.

\section{APPENDIX 9.}

Total volume of gastroliths in percent [\%] for day 1 to 4 and day 7 and 11 of crayfish sample $\mathrm{C}_{\text {tank }}, \mathrm{C}_{\text {tank }}, \mathrm{C}_{\text {tank }}$ and $\mathrm{C} 10_{\text {tank }}$ in tank water. 


\section{APPENDIX 10.}

Total volume of gastroliths in percent [\%] for day 1 to 4 and day 7 and 11 of crayfish sample $\mathrm{C} 1_{\text {dist. }}, \mathrm{C} 3_{\text {dist. }}, \mathrm{C} 4_{\text {dist. }}, \mathrm{C} 8_{\text {dist. }}, \mathrm{C} 9_{\text {dist. }}$, and $\mathrm{C} 10_{\text {dist. }}$ in distilled water.

\section{APPENDIX 11.}

Additional information on the crayfish samples used for AAS.

\section{APPENDIX 12}

Relationship between body size and maximum volume of precipitated calcite. 